\title{
Management of Hepatitis B Surface Antigen and Hepatitis C Antibody-Positive Patients by Departments Not Specializing in Hepatology at a Suburban University Hospital in Japan: A Single-Center Observational Study [Corrigendum]
}

Tokushima Y, Tago M, Tokushima M, et al. Int $J$ Gen The correct Table 1 is shown below:

Med. 2020;13:743-750.

The authors have advised there are errors in Table 1 on page 746 in the Hbs-Ag positive patients' data. The errors were introduced during the creation of the Table.

The errors were only in the patients' background and do not affect the main results (consultation rate, comparison of RF and non-RF groups), discussion, or conclusion of the paper.

The authors apologize for these errors.

Table I Characteristics of Hepatitis B Surface Antigen-Positive Patients and with Moderate to High Titers of Hepatitis C Virus Antibodies

\begin{tabular}{|c|c|c|c|c|}
\hline \multirow[b]{2}{*}{ Age (years) } & \multicolumn{2}{|c|}{ HBs-Ag-Positive } & \multicolumn{2}{|c|}{ Moderate to High HCV-Ab Titers } \\
\hline & 62.1 & \pm 17.7 & 69.3 & \pm 15.4 \\
\hline Male sex & 36 & $43.9 \%$ & 142 & $50.9 \%$ \\
\hline Internal medicine department & 16 & $19.5 \%$ & 60 & $21.5 \%$ \\
\hline $\operatorname{PLT}\left(\times 10^{4} / \mu \mathrm{L}\right)$ & 20.0 & \pm 7.7 & 17.2 & \pm 6.9 \\
\hline AST (U/L) & 55.5 & \pm 221.9 & 36.8 & \pm 40.4 \\
\hline ALT (U/L) & 67.6 & \pm 366.5 & 26.2 & \pm 23.4 \\
\hline$\gamma$-GTP (U/L) & 34.8 & \pm 33.8 & 36.9 & \pm 42.2 \\
\hline HBs-Ag (IU/mL) & 3967.2 & \pm 12371.6 & - & - \\
\hline HCV-Ab (S/CO) & - & - & 12.8 & \pm 3.8 \\
\hline Referred group & 29 & $35.4 \%$ & 33 & $11.8 \%$ \\
\hline
\end{tabular}

Notes: Nominal variables are expressed as numbers and percentages, continuous variables are expressed as mean and standard deviation.

Abbreviations: PLT, platelet count; AST, aspartate aminotransferase; ALT, alanine aminotransferase; $\gamma$-GTP, $\gamma$-glutamyl transpeptidase; HBs-Ag, hepatitis B surface antigen; HCV-Ab, hepatitis $C$ virus antibody.

International Journal of General Medicine

Dovepress

\section{Publish your work in this journal}

The International Journal of General Medicine is an international, peer-reviewed open-access journal that focuses on general and internal medicine, pathogenesis, epidemiology, diagnosis, monitoring and treatment protocols. The journal is characterized by the rapid reporting of reviews, original research and clinical studies

across all disease areas. The manuscript management system is completely online and includes a very quick and fair peer-review system, which is all easy to use. Visit http://www.dovepress.com/ testimonials.php to read real quotes from published authors. 